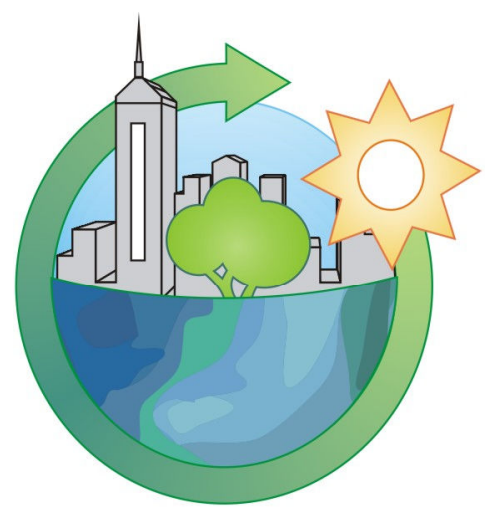

São Paulo - Brazil - May $-22^{\text {nd }}$ to $24^{\text {th }}-2013$

INTERNATIONAL WORKSHOP

ADVANCES IN CLEANER PRODUCTION

“INTEGRATING CLEANER PRODUCTION INTO SUSTAINABILITY STRATEGIES"

\title{
Energy Production from Microalgae Biomass: The Carbon Footprint and Energy Balance
}

\author{
MEDEIROS, D. L. ${ }^{a *}$, SALES, E. A. ${ }^{a}$, KIPERSTOK, A. ${ }^{a}$ \\ a. Universidade Federal da Bahia, Salvador \\ *Corresponding author, diegomedeiros350@gmail.com
}

\begin{abstract}
Bioenergy sources are promising alternatives for energy production in a sustainable world. Nevertheless many research and detailed analysis are necessary to measure in which circumstances they can contribute to it. This paper focuses on microalgae biomass combustion to produce heat and compares the use of different electricity sources with respect to Greenhouse Gas (GHG) emissions and Net Energy Ratio (NER). Some fossil sources were used as reference. The methodology was based on ISO 14040/44 standards and most of the data were obtained from scientific publications. The results showed that NER from microalgae combustion is still disadvantageous compared to fossil options. Microalgae GHG emissions were higher than fossil using the United States electricity grid but lower using the Brazilian one. Regardless of the fossil options show slightly better yields related to microalgae in the two categories analyzed, the fossil energy technology is mature and has less space for improvements while microalgae is in its infancy and have many technological solutions being developed.
\end{abstract}

Keywords: Microalgae, Life Cycle Analysis, Greenhouse Gas, Net Energy Ratio.

\section{Introduction}

The world economy relies on energy to keep its growth. The more diverse are the energy sources more technology will be developed over time, minimizing the risk of an energy crisis. Fossil fuels represent around $80 \%$ of the world energy demand and are relatively cheap to produce. On the other hand they have caused some social-political problems and added $\mathrm{CO}_{2}$ into the atmosphere, contributing to the climate change.

The bioenergy industry is very diverse and will play a decisive role in the world energy sector as the technology matures. New ways of biomass-to-energy conversion are in development. Microalgae-toenergy is being studied in the last decades and some industrial plants are being built to start its commercialization (AIM, 2013). The technology to grow and process algae varies according to the location, specie being grown and the products intended to be taken. Davis, Aden and Pienkos (2011) declared that there is a wide lack of public agreement on the near-term economic viability of algal biofuels, due to uncertainties and speculation on process scale-up associated with the emerging stage of the algal biofuel industry.

This paper intends to assess qualitatively the microalgae bioenergy production. It examined some of the latest discoveries into this field and simulated a case study. 


\section{Microalgae-to-bioenergy}

\subsection{Cultivation data}

The first step to grow microalgae is decisive as it normally demands most of the resources and energy. A comparative assessment of microalgae inventory was conducted at the cultivation step to check the consistency, based on the data shown in Tables 1 and 2.

Table 1 - Microalgae cultivation inventory in Open-ponds per kilogram of dry matter.

\begin{tabular}{|c|c|c|c|c|c|c|c|c|c|c|}
\hline \multicolumn{2}{|l|}{ Method } & \multicolumn{9}{|c|}{ Open Ponds } \\
\hline \multicolumn{2}{|l|}{ Authors } & $\begin{array}{l}\text { Chisti, } \\
2007 .\end{array}$ & $\begin{array}{l}\text { Lardon } \\
\text { et al., } \\
2009 .\end{array}$ & $\begin{array}{l}\text { Lardon } \\
\text { et al., } \\
2009 .\end{array}$ & $\begin{array}{c}\text { Jorquera } \\
\text { et al., } \\
2009 \\
\end{array}$ & $\begin{array}{c}\text { Campbell } \\
\text { et al., } \\
2010 . \\
\end{array}$ & $\begin{array}{l}\text { Clarens } \\
\text { et al., } \\
2010 .\end{array}$ & $\begin{array}{c}\text { Stephenson } \\
\text { et al., } \\
2010 .\end{array}$ & $\begin{array}{l}\text { Quinn } \\
\text { et al., } \\
2011 .\end{array}$ & $\begin{array}{c}\text { Razon e } \\
\text { Tan, } \\
2011 . \\
\end{array}$ \\
\hline Espécie: & & $\begin{array}{l}\text { Chlorella } \\
\text { vulgaris }\end{array}$ & $\begin{array}{l}\text { Chiorella } \\
\text { volgaris, } \\
\text { Normal }\end{array}$ & $\begin{array}{l}\text { Chiorella } \\
\text { vulgaris, } \\
\text { pouco N }\end{array}$ & $\begin{array}{c}\text { Nannoch } \\
\text { oropsis } \\
\text { sp. }\end{array}$ & Ounaliella & $\begin{array}{l}\text { Mix of } \\
\text { microalgae }\end{array}$ & $\begin{array}{c}\text { chilorella } \\
\text { vulgaris }\end{array}$ & $\begin{array}{l}\text { Nannochl } \\
\text { oropsis } \\
\text { oculata }\end{array}$ & $\begin{array}{c}\text { Nannoch } \\
\text { oropsis } \\
\text { sp. }\end{array}$ \\
\hline Input & Unit & \multicolumn{9}{|c|}{ Quantity } \\
\hline Energy & kwh & - & 0,35 & 0,42 & 1,05 & 0,2 & 0,19 & 0,8 & - & 12,7 \\
\hline $\mathrm{CO}_{2}$ & $\mathrm{~kg}$ & 1,83 & 1,75 & 1,97 & - & 1,69 & - & - & - & - \\
\hline$N$ & $\mathrm{~kg}$ & 0,07 & 0,046 & 0,01 & - & 0,008 & - & 0,024 & - & 0,007 \\
\hline $\bar{P}$ & $\mathrm{~kg}$ & 0,01 & - & - & - & 0,0056 & - & - & - & 0,013 \\
\hline Water & $\mathrm{m}^{3}$ & 7,1 & - & - & 2,8 & 0,7 & - & 0,7 & - & - \\
\hline Growth & $g / \mathrm{m}^{2}$.dia & - & 25 & 19 & 11 & 30 & 15 & 30 & 15 & 16 \\
\hline Concentration & $\mathrm{kg} / \mathrm{m}^{3}$ & 0,1 & 0,5 & 0,5 & 0,35 & - & 1 & 1,67 & 3 & 0,13 \\
\hline Oil content & $\%$ & 30 & 18 & 40 & 30 & - & - & 40 & 51 & 30 \\
\hline
\end{tabular}

Table 2 - Microalgae cultivation inventory in Photobioreactors per kilogram of dry matter.

\begin{tabular}{|c|c|c|c|c|c|c|c|c|}
\hline \multicolumn{2}{|l|}{ Method } & \multicolumn{3}{|c|}{ Tubular } & \multirow{2}{*}{\begin{tabular}{|c|} 
Flat-plate \\
Jorquera \\
et al., \\
2009
\end{tabular}} & \multicolumn{2}{|c|}{ Hybrid [FPP-OP] } & \multirow{2}{*}{$\begin{array}{c}\text { Polyethylene bags } \\
\text { Batan } \\
\text { et al., } \\
2010 .\end{array}$} \\
\hline Author & & $\begin{array}{l}\text { Chisti, } \\
2007 \text {. }\end{array}$ & $\begin{array}{l}\text { Collet } \\
\text { et al., } \\
2010 .\end{array}$ & $\begin{array}{c}\text { Stephenson } \\
\text { et } \mathrm{al} ., \\
2010 .\end{array}$ & & $\begin{array}{l}\text { Khoo } \\
\text { et al., } \\
2011 .\end{array}$ & $\begin{array}{c}\text { Razon e } \\
\text { Tan, } \\
2011 . \\
\end{array}$ & \\
\hline Specie & & $\begin{array}{l}\text { Chlorella } \\
\text { vulgaris }\end{array}$ & $\begin{array}{l}\text { Chlorella } \\
\text { vulgaris }\end{array}$ & $\begin{array}{c}\text { Chlorella } \\
\text { vulgaris }\end{array}$ & $\begin{array}{l}\text { Nannoch } \\
\text { oropsis } \\
\text { sp. }\end{array}$ & $\begin{array}{l}\text { Nannoch } \\
\text { oropsis } \\
\text { sp. }\end{array}$ & $\begin{array}{c}\text { Haematoc } \\
\text { ocous } \\
\text { pluvialis }\end{array}$ & $\begin{array}{l}\text { Nannochioropsis } \\
\text { salina }\end{array}$ \\
\hline Input & Unit & \multicolumn{7}{|c|}{ Quantity } \\
\hline Energy & kwh & - & 0,23 & 7,27 & 1,94 & 0,972 & 5,77 & 0,455 \\
\hline $\mathrm{CO}_{2}$ & $\mathrm{~kg}$ & 1,83 & 1,17 & - & - & 1,83 & - & - \\
\hline $\mathrm{N}$ & $\mathrm{kg}$ & 0,07 & 0,01 & 0,0236 & - & 0,15 & 0,0128 & 0,147 \\
\hline$P$ & $\mathrm{~kg}$ & 0,01 & 0,002 & - & - & 0,01 & 0,013 & 0,02 \\
\hline Water & $\mathrm{m}^{3}$ & 0,25 & - & 0,134 & 0,37 & 2,125 & - & 0,134 \\
\hline Growth & $g / \mathrm{m}^{2} \cdot \mathrm{dia}$ & - & 25 & 75 & 27 & - & 16 & 25 \\
\hline Concentration & $\mathrm{kg} / \mathrm{m}^{3}$ & 4 & 0,5 & 8,3 & 2,7 & 0,5 & 0,43 & - \\
\hline Oil content & $\%$ & 30 & - & 40 & 30 & - & 25 & - \\
\hline
\end{tabular}

\subsection{Scaling-up}

Significant improvements in the efficiency, cost structure and ability to scale-up algal growth, lipid extraction, and biofuel production must be made to produce commercially viable bioenergy from microalgae. A defined set of technology breakthroughs will be required to develop the optimum utilization of microalgae biomass aiming commercial production of biofuels (Singh and Olsen, 2011, Um et al., 2009). Table 3 summarizes most of them.

Table 3 - Microalgae to biofuel obstacles for commercial scale implementation. 


\begin{tabular}{|c|c|c|}
\hline Cultivation & Opportunities & Challenges \\
\hline $\mathrm{CO}_{2}$ & $\begin{array}{l}\text { From energy intensive industrial } \\
\text { plants }^{1}\end{array}$ & Land shortage around these industrial areas ${ }^{2}$ \\
\hline Nutrients & $\begin{array}{l}\text { From secondary wastewater } \\
\text { treatment plants }\end{array}$ & Not well studied yet ${ }^{3}$ \\
\hline Water & Can be recirculated & This practice is not well established yet ${ }^{4}$ \\
\hline Infrastructure and Operation & Offer more control to the processes & High cost and currently is intensive in energy $y^{5}$ \\
\hline Sun/light & Arid areas are one promising source & $\begin{array}{l}\text { The resources shoud be transported through long } \\
\text { distances and it needs investment in infrastructure }\end{array}$ \\
\hline Temperature & $\begin{array}{l}\text { Places surround mountains, ralnforest } \\
\text { or big water bodies have amene } \\
\text { temperatures }\end{array}$ & $\begin{array}{l}\text { Normally these places are protected. In arid areas } \\
\text { temperature control may impose a challenge }\end{array}$ \\
\hline Specie & $\begin{array}{l}\text { It is been used wid types of algae, } \\
\text { without much selection or } \\
\text { improvement }\end{array}$ & The algae will have to be domesticated ${ }^{3}$ \\
\hline Oil productivity & $\begin{array}{l}\text { Starve algae from nitrogen increase } \\
\text { lipid's productivity }\end{array}$ & Slow down growth yield and consequently operation costs \\
\hline Contamination & $\begin{array}{l}\text { Microalgae from lab did not stand } \\
\text { under robust conditions encountered } \\
\text { in the field }\end{array}$ & $\begin{array}{l}\text { Allow a contaminant native to the area take over the } \\
\text { ponds }{ }^{6}\end{array}$ \\
\hline Harversting & $\begin{array}{l}\text { There are many technologies being } \\
\text { used and in development }\end{array}$ & $\begin{array}{l}\text { It has to be adapted for a specific specie, medium and } \\
\text { downstream process? }\end{array}$ \\
\hline Lipid extraction & \begin{tabular}{|l} 
There are promising technologies \\
being developed
\end{tabular} & $\begin{array}{l}\text { It will depend on the specie of algae and how it was } \\
\text { grown }\end{array}$ \\
\hline Biomass & $\begin{array}{l}\text { It can be converted in many forms of } \\
\text { biofuels. }\end{array}$ & $\begin{array}{l}\text { Not all of them have being successtul tested in pilot scale } \\
\text { yet }^{9}\end{array}$ \\
\hline
\end{tabular}

Sources: Campbell et al. (2010) ${ }^{1}$; Pate et al. (2011) ; Park et al. (2011) \& Christenson and Sims (2011) ; Yang et al. $(2011)^{4}$; Norsker et al. $(2011)^{5}$; Sheehan et al. $(1998)^{6}$; Uduman et al. (2010) \& Mata et al. (2010) ; Rawat et al. (2011) \& Benemann (2010) ${ }^{8}$; Singh and Olsen $(2011)^{9}$; Lardon et al. (2009) ${ }^{10}$.

Biofuels based on algal biomass may play a decisive role in the future energy systems if these technological breakthroughs occur. It is still too early for comments on any preferred routes of biofuels production from algal biomass at the current stage of development (Singh and Olsen 2011).

The carbon dioxide input can be supplied from external sources such as flue gases from boilers, furnaces or power plants to nourish the growth of microalgae (Sander and Murthy, 2010; Campbell et al., 2010). Other studies found that some combustion products such as nitrogen oxides and sulfur oxides can be effectively used by microalgae as nutrients (Um et al., 2009; Packer, 2009; Yoo et al. 2009). The source of nutrients, according to Yang et al. (2010), may come from municipal wastewater after secondary treatment containing all nutrients needed for algal growth except carbon. The U.S. DOE (2010) states that in favorable climates microalgae represent a more advantageous technological alternative over conventional tertiary treatment technologies for nutrient removal. According to Park et al. (2011) and Pittman et al. (2011) the use of wastewater is shown as the most economically way to produce microalgae biomass sustainably with the minimal environmental impact. On the other hand Christenson and Sims (2011) claim that only a few preliminary studies were conducted on the microalgae biofuels and bioproducts production grown in wastewater. Table 4 shows comparatively the conclusions from some energy analyze studies of different microalgae biofuels conducted by distinct groups. Some studies found positive and negative results, depending on the technological scenario modeled.

Table 4 - Comparison of energy balance results of microalgae biofuel production over the life cycle.

\begin{tabular}{|c|c|c|c|}
\hline Studies & Routes & Positive & Negative \\
\hline Lardon et al (2009) & Biodiesel production from microalgae & $\mathrm{X}$ & \\
\hline Clarens et al (2010) & Biomass production from microalgae & $\mathrm{X}$ & \\
\hline Liu et al (2009) & Methanol production from microalgae & $\mathrm{X}$ & \\
\hline Scott et al (2010) & Biodiesel production from microalgae & & $\mathrm{X}$ \\
\hline Jorquera et al (2010) & Biomass production using different methods & $\mathrm{X}$ & $\mathrm{X}$ \\
\hline Liu et al (2011) & Biodiesel produced from six microalgae (raceway) models & $\mathrm{X}$ & $\mathrm{X}$ \\
\hline Razon and Tan (2011) & Biodiesel and methane produced from microalgae & & $\mathrm{X}$ \\
\hline
\end{tabular}


Clarens et al. (2011) compared different routes of energy production from microalgae biomass such as: biogas electricity and biodiesel, direct biomass combustion for electricity and biodiesel, and biomass combustion for electricity only. All of the products from each route were intended for transportation. The authors concluded the most energy outcome, or best NER, came from combusting biomass. Extracting lipids to produce biodiesel was very inefficient.

\section{Methods}

The case study aimed to evaluate the energy and environmental performance of thermal recovery of biomass combustion from microalgae, cultivated in Open Ponds (OP) and Flat Plate Photobioreactors (FPP). It focused on the NER and GHG emissions in a life cycle perspective. The results were compared with some fossil sources. Most of the data used in this analysis came from scientific literature, since there weren't any commercial industrial plants producing bioenergy photosynthetically out of microalgae till this moment.

\subsection{Goal and scope}

This study was based on the methodology of Life Cycle Assessment (LCA) (ISO 14040/44, 2009). For each route two scenarios for cultivation of the species Nannochloropsis sp.were considered:

OP1 - algal biomass, open pond, residual $\mathrm{CO}_{2}$.

OP2 - algal biomass, open pond, residual $\mathrm{CO}_{2}$ and wastewater.

FPP1 - algal biomass, flat plate, residual $\mathrm{CO}_{2}$.

FPP2 - algal biomass, flat plate, residual $\mathrm{CO}_{2}$ and wastewater.

The production of residual $\mathrm{CO}_{2}$ did not have any environmental burden on its production for all scenarios since it was considered as a waste product of combustion processes. Yoo et al. (2009) found the use of flue gases not to cause any change in the productivity of microalgae. The sequestration of $\mathrm{CO}_{2}$ by microalgae was not taken into account since the combustion process releases it back into the atmosphere. The emission of the other flue gases was considered. The scenarios OP2 and FPP2 used wastewater as nutrient source and replaced chemical fertilizers without productivity loss (Yang et al., 2010; Jiang et al. 2011; Perelo et al., 2012). The water supply was complemented with tailing water from desalination since the specie used was Nannochloropsis sp.

\subsection{Inventory}

The functional unit adopted was 1 kilogram $(\mathrm{kg})$ of biomass with Higher Heating Value of 20 Mega Joules (MJ) and Lower Heating Value (LHV) of $18.26 \mathrm{MJ}$. The infrastructure materials of the cultivation and harvesting step were disregarded since the impact was assumed to be negligible along the lifespan of the building. The following assumptions were considered for the definition of the system model:

\section{a) Cultivation}

The electricity consumption in cultivation stage is due to pressurization and pumping of carbon dioxide in the culture medium, water recirculation, and cooling in the case of FPP (Jorquera et al. 2009). The source of electricity used firstly was the American Electric Grid, named Electricity, medium voltage, at grid / U.S. in the Ecoinvent database v2.2 (2013), due to the data on microalgae biomass productivity and concentration rate be modeled for the United States by Jorquera et al. (2009).

The flue gas, water supply and wastewater were assumed to be located close to the microalgae farms, needing no further transport requirements. The water may come from the sea or saline aquifers, common in the the semiarid northeastern of Brazil, needed to be desalted to supply the population and generating tailings water as a byproduct of which has been indicated as a favorable growth medium for Nannochloropsis sp. together with treated wastewater reuse (Perelo et al., 2012; Jiang et al., 2011). All water in both systems were recirculated. The losses by evaporation in the OP system weren't considered owing that all the water were previously wastewater. The OP1 and FPP1 scenarios used commercial fertilizers produced in Europe with its energy mix coming mostly from fossil.

"INTEGRATING CLEANER PRODUCTION INTO SUSTAINABILITY STRATEGIES"

$$
\text { São Paulo - Brazil - May } 22^{\text {nd }} \text { to } 24^{\text {th }}-2013
$$


The data of biomass concentration at the point of harvest were $0.35 \mathrm{~kg} / \mathrm{m}^{3}$ in OP and $2.7 \mathrm{~kg} / \mathrm{m}^{3} \mathrm{FPP}$ (Jorquera et al. 2009). These data also served to estimate the volume of medium cultivation needed for each kilogram of microalgae biomass harvested. According Jorquera et al. (2009) maximum concentration would be achieved in 7 days.

b) Harvest

The inventories of flocculates production were also europeans. After three processes of harvesting (flocculation, decantation and centrifugation) and a drying stage (solar-greenhouse) the biomass would be apt for energy recovery by combustion to generate heat. The solar-greenhouse doesn't require any significant direct input besides sunlight, then this step was disregarded from the inventory.

c) Combustion

Due to lack of data of microalgal biomass burning, it was decided to take an representative inventory from Ecoinvent. The inventory of a thermoelectric powered by household perishable waste was chosen due to the elemental analysis of this source be the closest inventory available on SimaPro 7.3 to microalgae one regarding the $\mathrm{C} / \mathrm{N}$ fraction. This inventory includes consumption of electricity, transportation, infrastructure and losses for the useful heat recovery from firing. The Lower Heating Value (LHV) was calculated for Nannochloropsis sp. biomass, Appendix I. Figure 1 shows the system boundaries.

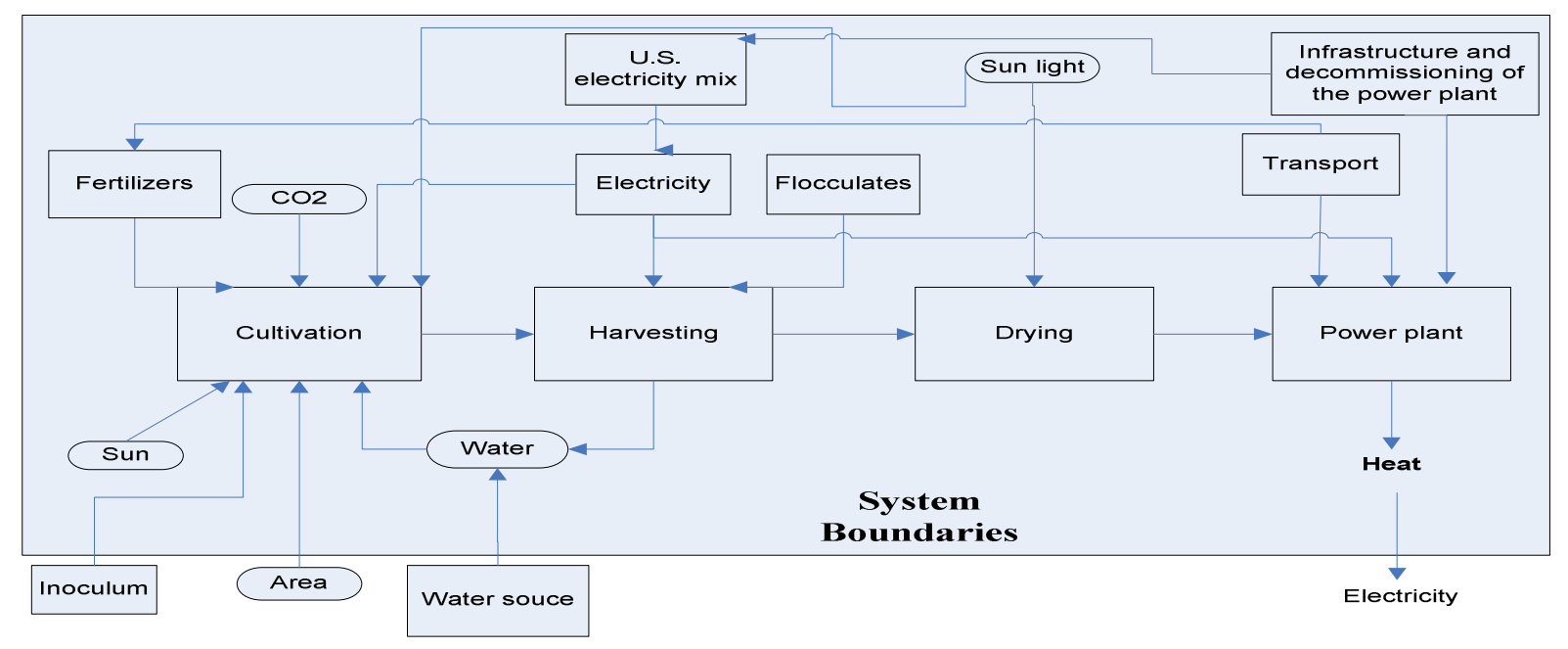

Figure 1 - Thermal energy production chain from microalgae biomass.

\subsection{Inventory Analysis}

Tabela 5 - Microalgae biomass from Nannochloropsis sp. production inventory per kilogram of dry matter in Open-ponds (OP) and Flat-plate photobioreactor (FPP).

\begin{tabular}{|c|c|c|c|c|}
\hline Inputs & OP & FPP & Unit & Source \\
\hline \multicolumn{5}{|l|}{ CULTIVATION } \\
\hline Nitrogen $(\mathrm{N})$ & 0,07 & 0,07 & $\mathbf{k g} / \mathbf{k g}$ & Calculated \\
\hline Phosphorus (P) & 0,01 & 0,01 & $\mathbf{k g} / \mathbf{k g}$ & Calculated \\
\hline Potassium (K) & 0,01 & 0,01 & $\mathbf{k g} / \mathbf{k g}$ & Calculated \\
\hline Fertilizers transportation & 0,02 & 0,02 & t.km & Estimated \\
\hline Carbon dioxide (CO2) & 1,83 & 1,83 & $\mathbf{k g} / \mathbf{k g}$ & Chisti 2007 \\
\hline Water & 2857,14 & 370,37 & $\mathbf{k g} / \mathbf{k g}$ & Jorquera et al. 2009 \\
\hline Electricity & 1,05 & 1,94 & $\mathbf{k W h} / \mathbf{k g}$ & Jorquera et al. 2009 \\
\hline Microalgae + Water & 2858,14 & 371,37 & $\mathbf{k g} / \mathbf{k g}$ & \\
\hline \multicolumn{5}{|l|}{ FLOCULATION } \\
\hline Aluminum Sulfate $\mathrm{Al} 2\left(\mathrm{SO}_{4}\right)_{3}$ & 1,3 & 1,3 & $\mathbf{k g} / \mathbf{k g}$ & Razon and Tan 2011 \\
\hline Hydrochloric Acid HCL (15\%) & 0,3 & 0,3 & $\mathbf{k g} / \mathbf{k g}$ & Razon and Tan 2011 \\
\hline Microalgae + moisture & 8 & 1,04 & $\mathbf{k g} / \mathbf{k g}$ & \\
\hline \multicolumn{5}{|l|}{ CENTRIFUGATION } \\
\hline Electricity & 0,06 & 0,001 & kWh/kg Water & Brentner et al. 2011 \\
\hline
\end{tabular}

“INTEGRATING CLEANER PRODUCTION INTO SUSTAINABILITY STRATEGIES”

São Paulo - Brazil - May 22 $2^{\text {nd }}$ to $24^{\text {th }}-2013$ 


\section{Results}

\subsection{Net Energy Ratio}

The Net Energy Ratio (NER) is calculated from the energy contained in the final product, the output energy ( $E$ Out), divided by the sum of cumulative energy demand or input energy ( $E$ In) from the system.

$\mathrm{NER}=\mathrm{E}$ Out $/ \Sigma \mathrm{E}$ In

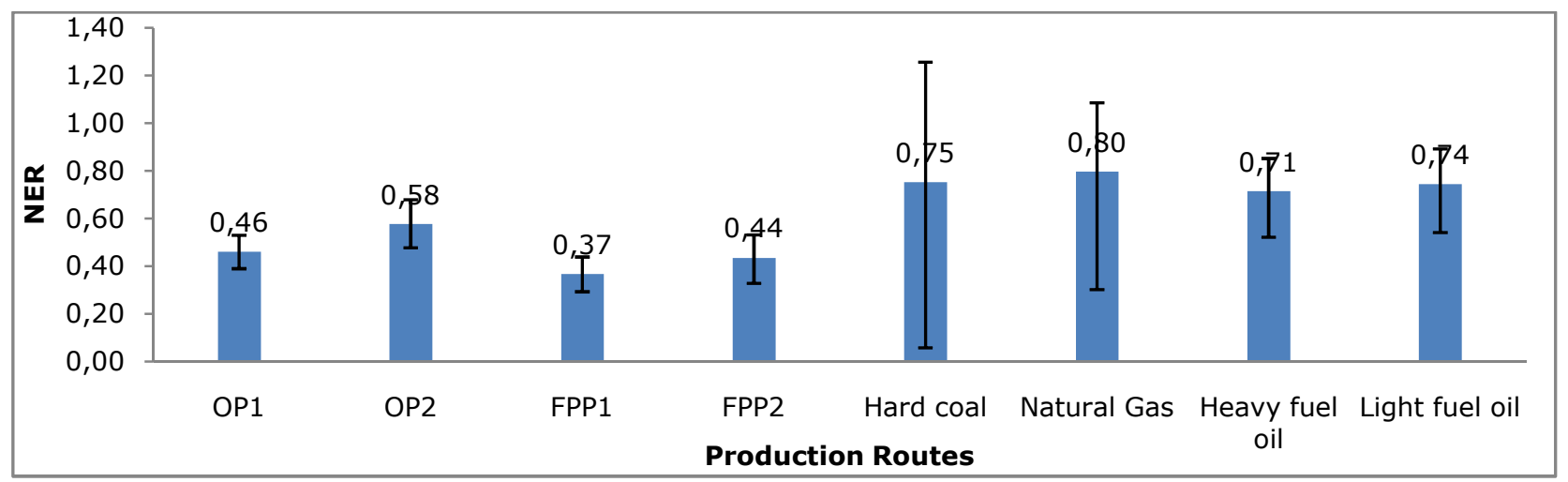

Figure 2 - Energy balance of 20 Mega Joules (LHV) from Nannochloropsis sp. at OP1, OP2, FPP1 and FPP2 and the fossil options. Source: Cumulative Energy Demand (CED) method from Ecoinvent v2.2 (2013).

\subsection{GHG emissions}

Figure 3 presents the emissions of GHG of the routes OP1, OP2, FPP1 and FPP2 calculated based on the impact assessment method from IPCC (2007) 100 years using the inventory data on the SimaPro 7.3® software and compared with some fossils options of the Ecoinvent v2.2 database as follows Heat, at hard coal industrial furnace 1-10MW/RER U; Heat natural gas, at industrial furnace $>100 \mathrm{~kW} / R E R \mathrm{U}$, Heat, heavy fuel oil, at industrial furnace $1 M W / R E R U$; Heat, light fuel oil, at industrial furnace $1 M W / R E R U$.

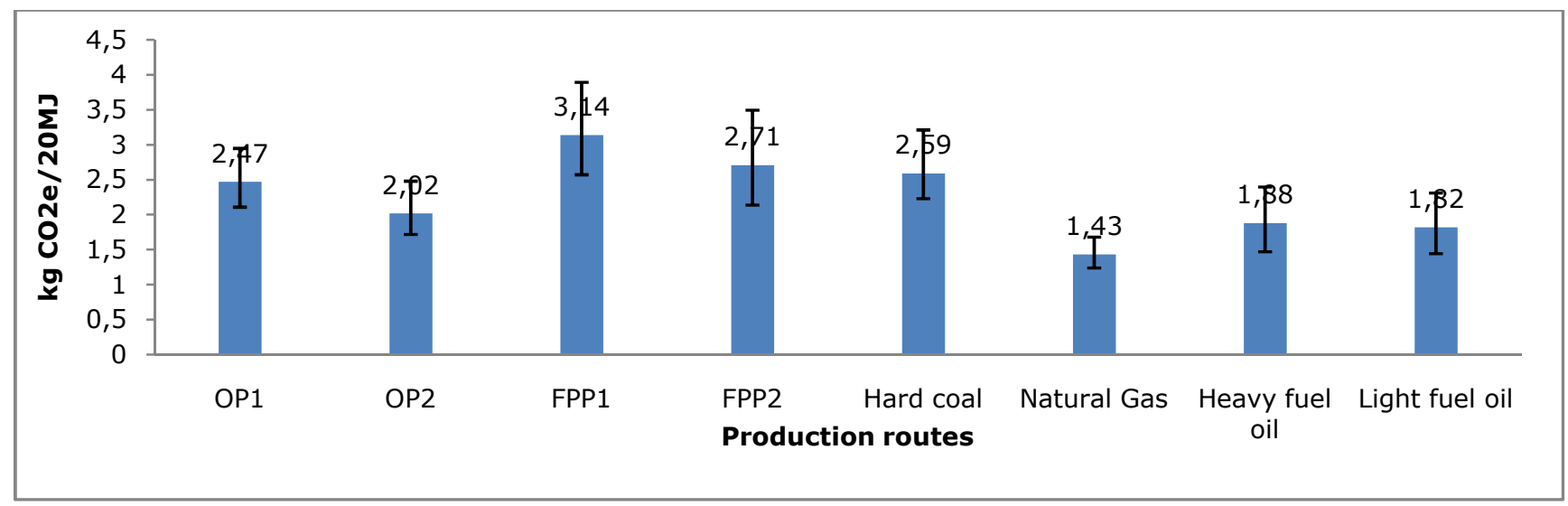

Figure 3 - GHG emissions from OP1, OP2, FPP1, FPP2 and some fossil options referred to the production of $20 \mathrm{MJ}$ (LHV) of thermal energy at the power plant.

Figure 4 shows the input processes used in each step along the production chain and their GHG contribution to the final product related to the OP1 route. The others are similar. 


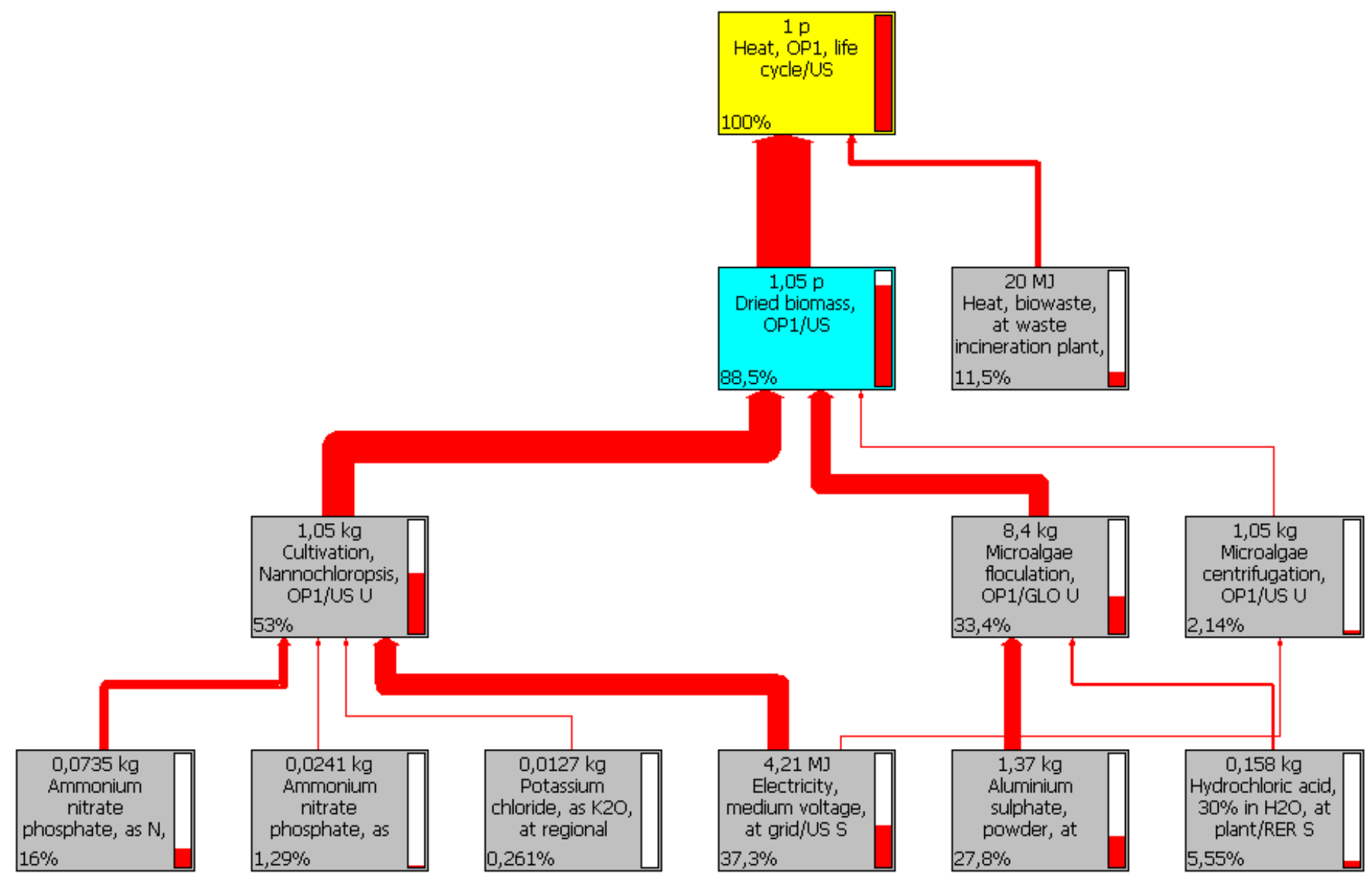

Figure 4 - Relative GHG emissions per processes from thermal energy production of OP1. Source: SimaPro $7.3 \circledR$.

It was checked the natural gas GHG emissions from the Ecoinvent database and found that 83,3\% occur in the combustion step. The reason is due to the carbon dioxide fossil be accounted differently from the biogenic one.

\section{Discussion}

The cultivation of microalgae is quite electricity intensive for pumping, recirculation and injection of air with high levels of carbon dioxide in the cultivation medium. This paper found the biomass of microalgae for combustion and thermal recovery wasn't viable yet in an energy point of view at first, disagreeing with Clarens et al. (2011). Surprisingly, fossil options proved viable despite of the great uncertainties.

There are several optimization opportunities to increase eco-efficiency production of microalgae such as those shown in Table 1. Even though they are not consolidated yet as an alternative source of energy production, studies like these are valuable to point potential and environmental aspects to drive the economic viability and the sustainability of microalgae technology implementation.

The OP2 and FPP2 scenarios performed more favorable than the formers OP1 and FPP1 in both categories assessed, NER and GHG, due to non-use of commercial fertilizers, as they require significant energy intake for producing and transporting, while wastewater contains these fertilizers already "for free". The substitution of commercial fertilizers by effluent brought an expressive gain in NER of 25$30 \%$.

The impact of fertilizer replacement by wastewater in the category of GHG was expressive too. 
Nevertheless the microalgae emission scenarios are considered statistically equal to most fossils due to uncertainties. The natural gas is an exception with the best performance. It is noteworthy that the source of electricity used in the entire chain of all microalgae scenarios analyzed were from the U.S. electrical grid, predominantly fossil.

In order to identify the influence of the electricity source in the scenarios of this study, we decided to test the performance of the Brazilian energy grid in the cultivation step. Inputs such as fertilizers and flocculants continued with their original european electricity mix since most of these products are imported. The result graphs are in the Appendix II. The scenarios OP1, OP2, FPP1 and FPP2 increased $28,36,42$ and $55 \%$ on their NER and decreased $32,38,42$ and $50 \%$ on their GHG emissions respectively. The fact that the Brazilian energy matrix is less GHG intensive than the world average puts it in a better position to promote such kind of renewables.

In the cultivation step of scenarios OP1 and FPP1 the use of electricity and fertilizers amounted the largest contribution of GHG emissions. The largest contribution among the fertilizers was the nitrogenous. In scenarios OP2 and FPP2, with no commercial fertilizers, the use of electricity predominated as the major contributor of GHG emissions. In the harvesting step the major GHG contributor was the flocculent aluminum sulfate due to the high electricity consumption and its source be the European grid, predominantly fossil.

Comparing the data used in the case study with the others from literature review, Tables 1 and 2, it can be noticed some differences in the input and output parameters. For example, the consumption of electricity to produce $1 \mathrm{~kg}$ of microalgae biomass for open ponds of the case study was $1.05 \mathrm{kWh}$ while, despite the use of different species of microalgae, most authors ranged from 0.19 to $0.42 \mathrm{kWh}$, with the exception of Stephenson et al. (2010) and Razon and Tan (2011). The change of this parameter would cause a reduction between $60-80 \%$ on electricity consumption in this step. The photobioreactors would have a difference even greater, since the case study considered a consumption of $1.94 \mathrm{kWh}$ to produce $1 \mathrm{~kg}$ of microalgae in flat plate photobioreactors, whereas most authors ranged these values from 0.3 to $0.94 \mathrm{kWh}$, again with the exception of Stephenson et al. (2010) and Razon and Tan (2011). These differences represent a potential reduction from 52 to $85 \%$ on electricity consumption, which had the biggest contribution in the NER and GHG emissions.

A possible reduction of $70 \%$ of electricity consumption at the cultivation stage of OP2 would reduce the GHG emissions in approximately $42 \%$ of the final product resulting in an emission of $0.85 \mathrm{~kg} \mathrm{CO}_{2} \mathrm{e}$, putting this scenario in a better position in comparison with the best fossil option. In relation to the energy balance applying the same reduction in electricity consumption would represent a technological breaking point, resulting in the viability of the scenario OP2, achieving a NER of 1 . When the microalgae NER is greater than 1 it will be able to produce its own energy reducing sensibly the GHG emissions by cutting fossil based electricity. This simulation demonstrates how economic and environmental solutions may come together.

Figure 8 shows the majority of GHG emissions from natural gas, which is likewise similar to the other fossil sources, comes from the combustion step. This condition indicates there is little field to reduce GHG emissions along the fossil chain since its emission is relatively low and the technology used is mature. Actually the trend is increased costs of extracting fossil sources as long as they get scarcer. The microalgae scenarios have smaller GHG contributions at the combustion step due to the $\mathrm{CO}_{2}$ emitted on this stage be considered biogenic and disregarded by the GHG accounting methodologies as it is supposed to be considered already previously (avoiding double counting). Therefore the microalgae technology situation provides more chances to minimize the GHG emissions along the supply chain in the near future.

\section{Conclusion}

The results of this paper confirm the microalgae biomass potential as an energy source but warns the imperative decrease of energy, fertilizer and other inputs, like flocculants. The starting point for the economic and environmental viability of energy production from microalgae biomass is the achievement of a favorable energy balance. This study demonstrated that the use of residual $\mathrm{CO}_{2}$,

“INTEGRATING CLEANER PRODUCTION INTO SUSTAINABILITY STRATEGIES"

São Paulo - Brazil - May 22 $2^{\text {nd }}$ to $24^{\text {th }}-2013$ 
residual nutrients from other processes and different energy sources enable significant improvements in energy balance and reduce GHG emissions, increasing the chances for the commercial application of this technology in a competitive way. Some topics may be deepened in further research, such as evaluation of other environmental categories, local productivity rates and land use impacts at different regions, comparison with other renewable sources, and assessment of other routes for biomass energy conversion like: biodiesel, biomethane and bioethanol.

\section{References}

ISO 14040:2009 - Environmental Management - Life Cycle Assessment - Principles and framework.

Algae Industry Magazine (AIM). www.algaeindustrymagazine.com, Accessed in 30/01/2013.

Benemann, J., 2010. AIM Interview: Dr. John Benemann by David Schwartz. Algae Industry Magazine available at http://www.algaeindustrymagazine.com/the-aim-interview-dr-john-benemann/.

Brentner, L. B., Eckelman, M. J., Zimmerman, J. B., 2011. Combinatorial life cycle assessment to inform process design of industrial production of algal biodiesel. Environmental science \& technology, v. 45, n. 16, p. 7060-7. doi: 10.1021/es2006995.

Campbell, P. K., Beer, T.; Batten, D., 2010. Life cycle assessment of biodiesel production from microalgae in ponds. Bioresource technology. Elsevier Ltd. doi: 10.1016/j.biortech.2010.06.048.

Chisti, Y., Yan, J., 2011. Energy from algae: Current status and future trends. Applied Energy, v. 88, n. 10, p. 3277-3279. Elsevier Ltd. doi: 10.1016/j.apenergy.2011.04.038.

Christenson, L., Sims, R., 2011. Production and harvesting of microalgae for wastewater treatment, biofuels, and bioproducts. Biotechnology advances, v. 29, n. 6, p. 686-702. Elsevier Inc. doi: 10.1016/j.biotechadv.2011.05.015.

Clarens, A. F. et al., 2011. Environmental Impacts of Algae-Derived Biodiesel and Bioelectricity for Transportation. Env. Sci \& Tech. (45) 7554-7560.

Clarens, A. F., Resurreccion, E. P., White, M. A, Colosi, L. M., 2010. Environmental life cycle comparison of algae to other bioenergy feedstocks. Environmental science \& technology, v. 44, n. 5, p. 1813-9. doi: 10.1021 /es902838.

Davis, R., Aden, A., Pienkos, P. T., 2011. Techno-economic analysis of autotrophic microalgae for fuel production. Applied Energy, v. 88, n. 10, p. 3524-3531. Elsevier Ltd. doi: 10.1016/j.apenergy.2011.04.018.

Ecoinvent v2.2. 2013. Life Cycle Inventory Database. Disponível em www.ecoinvent.org

Jiang, L., Luo, S., Fan, X., Yang, Z., Guo, R., 2011. Biomass and lipid production of marine microalgae using municipal wastewater and high concentration of CO2. Applied Energy, v. 88, n. 10, p. 33363341. Elsevier Ltd. doi: 10.1016/j.apenergy.2011.03.043.

Jorquera, O., Kiperstok, A., Sales, E. A, Embiruçu, M., Ghirardi, M. L., 2010. Comparative energy lifecycle analyses of microalgal biomass production in open ponds and photobioreactors. Bioresource technology, v. 101, n. 4, p. 1406-13. Elsevier Ltd. doi: 10.1016/j.biortech.2009.09.038.

Lardon, L., Hélias, A., Sialve, B., Steyer, J.-P., Bernard, O., 2009. Life-Cycle Assessment of Biodiesel Production from Microalgae. Environmental Science Technology, v. 43, n. 17, p. 6475-6481. American Chemical Society. doi: 10.1021/es900705j.

Larsdotter, K., 2006. WasteWater treatment with microalgae - a literature review. avloppsrening med 
mikroalger - en litteraturstudie. Solar Energy, p. 31-38.

Liu, J., Ma, X., 2009. The analysis on energy and environmental impacts of microalgae-based fuel methanol in China. Energy Policy 37 (4) p. 1479-1488.

Liu, X., Clarens, A. F., Colosi, L. M., 2011. Algae biodiesel has potential despite inconclusive results to date. Bioresource Technology. Elsevier Ltd. doi: 10.1016/j.biortech.2011.10.077.

Mata, T. M., Martins, A. A., Caetano, N. S., 2010. Microalgae for biodiesel production and other applications: A review. Renewable and Sustainable Energy Reviews 14 217-232.

Norsker, N.-H., Barbosa, M. J., Vermuë, M. H., Wijffels, R. H., 2011. Microalgal production - a close look at the economics. Biotechnology advances, v. 29, n. 1, p. 24-7. Elsevier Inc. doi: 10.1016/j.biotechadv.2010.08.005.

Sheehan, J., Dunahay, T., Benemann, J., Roessler, P., 1998. A Look Back at the U.S. Department of Energy's Aquatic Species Program-Biodiesel from Algae. National Renewable Energy Laboratory (NREL) Report, available at http://www1.eere.energy.gov/biomass/pdfs/biodiesel_from_algae.pdf.

Park, J. B. K., Craggs, R. J., Shilton, A N., 2011. Wastewater treatment high rate algal ponds for biofuel production. Bioresource technology, v.102, n.1, p.35-42. doi: 10.1016/j.biortech.2010.06.158.

Pate, R., Klise, G., Wu, B., 2011. Resource demand implications for US algae biofuels production scaleup. Applied Energy, v. 88, n. 10, p. 3377-3388. Elsevier Ltd. doi: 10.1016/j.apenergy.2011.04.023.

Perelo, L. W., Sousa, L. L., Hora, D. S., 2012. Crescimento da microalga Nannochloropsis sp. em água salina do semi-árido com adição de esgoto domestico como fonte de nutrientes. II COBESA, Feira de Santana - BA.

Rawat, I., Kumar, R., Mutanda, T., Bux, F., 2011. Dual role of microalgae: Phycoremediation of domestic wastewater and biomass production for sustainable biofuels production. Applied Energy, $v$. 88, n. 10, p. 3411-3424. Elsevier Ltd. doi: 10.1016/j.apenergy.2010.11.025.

Razon, L. F. and Tan, R. R., 2011. Net energy analysis of the production of biodiesel and biogas from the microalgae: Haematococcus pluvialis and Nannochloropsis. Applied Energy, v. 88, n. 10, p. 350735142011.

Scott, S. A, Davey, M. P., Dennis, J. S., et al., 2010. Biodiesel from algae: challenges and prospects. Current opinion in biotechnology, v. 21, n. 3, p. 277-286. Elsevier Ltd. doi: 10.1016/j.copbio.2010.03.005.

Sforza, E., Bertucco, A.,, Morosinotto, T., Giacometti, G. M., 2011. Photobioreactors for microalgal growth and oil production with Nannochloropsis salina: From lab-scale experiments to large-scale design. Chemical Engineering Research and Design, n. December, p. 1-8. Institution of Chemical Engineers. doi: 10.1016/j.cherd.2011.12.002.

Sheehan, J., Dunahay, T., Benemann, J., Roessler, P., 1998. A Look Back at the U.S. Department of Energy's Aquatic Species Program-Biodiesel from Algae. National Renewable Energy Laboratory (NREL), available at http://www1.eere.energy.gov/biomass/pdfs/biodiesel_from_algae.pdf.

Singh, A., Olsen, S. I., 2011. A critical review of biochemical conversion, sustainability and life cycle assessment of algal biofuels. Applied Energy. Elsevier Ltd. doi: 10.1016/j.apenergy.2010.12.012.

U.S. DOE, 2010. National Algal Biofuels Technology Roadmap. U.S. Department of Energy, Office of Energy Efficiency and Renewable Energy, Biomass Program. Visit http://biomass.energy.gov for more information.

Uduman, N., Qi, Y., Danquah, M. K., Forde, G. M., and Hoadley, A., 2010. Dewatering of microalgal 
cultures: A major bottleneck to algae-based fuels. J. Renewable Sustainable Energy 2, 012701; doi:10.1063/1.3294480 (15 pages).

Um, B.-H., Kim, Y.-S., 2009. Review: A chance for Korea to advance algal-biodiesel technology. Journal of Industrial and Engineering Chemistry, v. 15, n. 1, p. 1-7. doi: 10.1016/j.jiec.2008.08.002.

Yang, J., Xu, M., Zhang, X., et al., 2011. Life Cycle Analysis on Biodiesel Production from Microalgae: Water Footprint and Nutrients Balance. Bioresource Technology. Elsevier Ltd. doi: 10.1016/j.biortech.2010.07.017.

Yoo, C., Jun, S. Y., Lee, J. Y., Ahn, C. Y., Oh, H. M., 2010. Bioresource Technology Selection of microalgae for lipid production under high levels carbon dioxide. Bioresource Technology, v. 101, n. 1, p. S71-S74. Elsevier Ltd. doi: 10.1016/j.biortech.2009.03.030.

\section{Apendix I}

The calculation of Lower Heating Value (LHV) was based on cellular composition of microalgae biomass, $\mathrm{CO}_{0,48} \mathrm{H}_{1,83} \mathrm{~N}_{0,11} \mathrm{P}_{0,01}$, given by Grobbelaar (2004 apud Chisti, 2007). The stoichiometric balance of combustion is $\mathrm{CO}_{0,48} \mathrm{H}_{1,83} \mathrm{~N}_{0,11} \mathrm{P}_{0,01}+2 \mathrm{O}_{2}->1 \mathrm{CO}_{2}+0.91 \mathrm{H}_{2} \mathrm{O}+0.11 \mathrm{NO}_{2}$

We considered the contribution of $\mathrm{P}$ disregarded in the stoichiometric balance. The water vaporization enthalpy $\left(\Delta \mathrm{HvapH}_{2} \mathrm{O}\right)$ at $20^{\circ} \mathrm{C}$ is $44.016 \mathrm{~kJ} / \mathrm{g}$.mol. Below see the calculation table of LHV from Nannochloropsis $s p$.

\begin{tabular}{|c|c|c|c|c|c|c|}
\hline & $\mathrm{C}$ & 0 & $\mathrm{H}$ & $\mathrm{N}$ & Comments & Lines \\
\hline Atomic weight & 12 & 16 & 1 & 14 & & 2 \\
\hline $\begin{array}{l}\text { Microalgae biomass molecular } \\
\text { composition }\end{array}$ & 1 & 0.48 & 1.83 & 0.11 & $\begin{array}{c}\text { Grobbelaar } 2004 \text { apud } \\
\text { Chisti } 2007 \\
\end{array}$ & 3 \\
\hline multiplication & 12 & 7.68 & 1.83 & 1.54 & Line $2 \times$ Line 3 & 4 \\
\hline \multirow[t]{6}{*}{ sum } & 23.05 & $\mathrm{~g} / \mathrm{g} \cdot \mathrm{mol}$ & & & Sum of Line 4 & 5 \\
\hline & \multicolumn{2}{|c|}{$1000 \mathrm{~g}$ or $1 \mathrm{~kg}$} & & & & 6 \\
\hline & $\mathrm{n}$ & 43.38 & g.mols & & Line 6 divided by Line 5 & 7 \\
\hline & $\begin{array}{l}\text { High Heating Value } \\
(\mathrm{HHV})\end{array}$ & 20 & $\mathrm{MJ} / \mathrm{kg}$ & & Sforza et al, 2011 & 8 \\
\hline & $1 \mathrm{gmol}$ of biomass & 0.91 & $\begin{array}{l}\text { gmol } \\
\mathrm{H} 2 \mathrm{O}\end{array}$ & & & 9 \\
\hline & vaporization enthalpy & 44.02 & $\mathrm{~kJ} / \mathrm{gmol}$ & & & 10 \\
\hline
\end{tabular}




\begin{tabular}{l|l|r|r|l|l|l} 
& of $\mathrm{H}_{2} \mathrm{O}$ & & & & & \\
\hline & & 40.05 & & & Line 9 $\times$ Line 10 & 11 \\
\hline & 1 Kg of biomass & 1737.72 & $\mathrm{~kJ}$ & & Line $11 \times$ Line 7 & 12 \\
\hline & or & 1.73 & $\mathrm{MJ}$ & & & 13 \\
\hline & LHV & $\mathbf{1 8 . 2 6}$ & $\mathrm{MJ}$ & & Line 8 - Line 13 & 14 \\
\hline & LHV/HHV & 0.91 & & Line 14 / Line 8 & 15 \\
\hline & or 1 LHV equivalent to & $1.10 \mathrm{HHV}$ & & $1 /$ Line 15 & 16 \\
\hline
\end{tabular}

\section{Appendix II}

\begin{tabular}{|c|c|c|c|c|c|}
\hline \multirow[t]{3}{*}{ 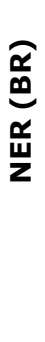 } & $\begin{array}{l}1,00 \\
0,80 \\
0,60 \\
0,40 \\
0,20\end{array}$ & $\stackrel{0,59}{\mathrm{I}}$ & 0,79 & $\stackrel{0,52}{\mathrm{I}}$ & 0,67 \\
\hline & & OP1 & OP2 & FPP1 & FPP2 \\
\hline & & & Pro & ios & \\
\hline
\end{tabular}

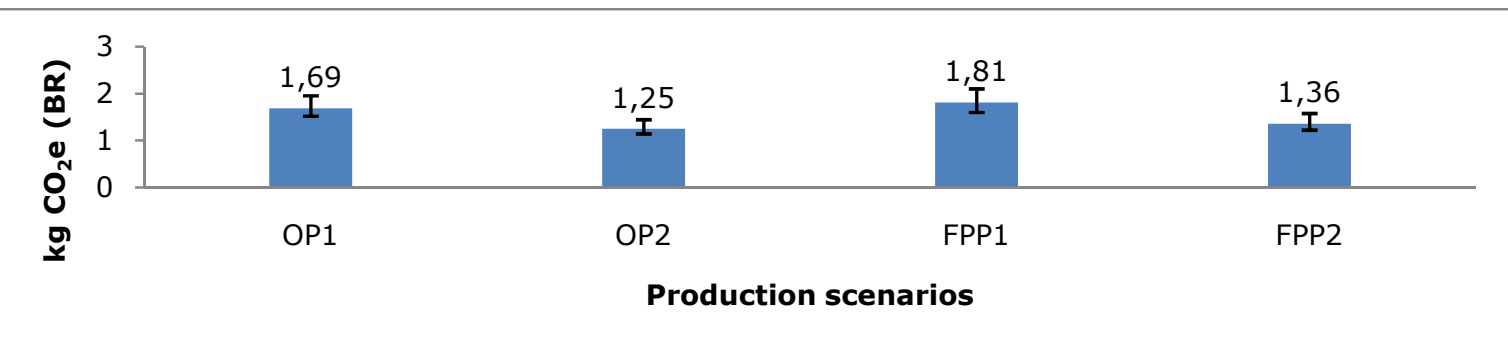

